\title{
An examination of the time course from human dietary exposure to polycyclic aromatic hydrocarbons to urinary elimination of 1-hydroxypyrene
}

\author{
Timothy J Buckley, Paul J Lioy
}

\begin{abstract}
The significance of diet as an exposure route for polycyclic aromatic hydrocarbons (PAHs) and the associated kinetics of urinary 1hydroxypyrene (1-OHPY) elimination were examined through a controlled human exposure study. Results showed that a 100 to 250-fold increase in a dietary benzo(a)pyrene (BaP) dose paralleled a four to 12-fold increase in urinary 1-OHPY elimination. Mean elimination rates during minimal exposure periods ranged from 6 to $17 \mathrm{ng} / \mathrm{h}$ whereas peak elimination rates of 60 to $189 \mathrm{ng} / \mathrm{h}$ were seen after a meal high in PAHs. A biexponential model fitted to a limited number of urinary 1-OHPY elimination points gave mean kinetic parameter estimates for $t_{1 / 2}$ of 4.4 hours and $t_{\max }$ of 6.3 hours. It is concluded that dietary exposure to PAHs is potentially as substantial as some occupational exposures and therefore requires consideration in studies of exposure to PAHs. The dietary control strategies and the kinetic parameters defined in this investigation provide data for the control of this exposure route when examining other sources of exposure.
\end{abstract}

Polycyclic aromatic hydrocarbons contaminate air, food, soil, and water, making human contact virtually

\footnotetext{
Joint Graduate Teaching Program in Exposure Assessment, Department of Environmental Science of Rutgers University and UMDNJ-Robert Wood Johnson Medical School, 675 Hoes Lane, Piscataway, New Jersey 08854-5635, USA

(Current address: MD-56, Atmospheric Research and Exposure Assessment Laboratory, US Environmental Protection Agency, Research Triangle Park, NC 27711)

T J Buckley

Environmental and Occupational Health Science Institute and the Department of Environmental and Community Medicine, UMDNJ-Robert Wood Johnson Medical School

P J Lioy
}

unavoidable. A biomarker of exposure provides a valuable means of assessing the extent and the significance of the human contact by giving a measurement that is direct and integrated over time and exposure routes. The utility of the pyrene metabolite 1-hydroxypyrene (1-OHPY) as a biomarker for occupational exposures to polycyclic aromatic hydrocarbons (PAHs) has been shown for inhalation and dermal routes. ${ }^{1-4}$ Dietary intake of PAHs is potentially substantial and therefore it is likely to be a confounding cofactor in its effect on urinary 1-OHPY concentrations when trying to isolate the effect of other exposure routes. The present study examines (1) the effect of dietary exposure on the urinary 1-OHPY elimination rate and (2) the time course of 1-OHPY elimination after the ingestion of a meal high in PAHs.

Biomarkers provide advantages in eliminating the uncertainties associated with host characteristics (for example, sex, age, diet, and activity) and the characteristics of the contaminant (for example, substrate, solubility, stability, and particle size). A biomarker, however, cannot differentiate the routes of exposure without knowledge of the concentration of the contaminant in the media and the subjects' contact with the media.

A biomarker of exposure is established by defining a predictive relation between external measures of exposure and biological concentrations. Because exposure and the appearance of the biomarker in urine does not occur simultaneously, relating these variables requires characterisation of their time course from contact through elimination.

Although investigation of PAH biomarkers (total or carcinogenic) is generally of interest, the analytical requirements for assaying many such compounds at trace concentrations are impractical. Attempts to develop biological markers for PAH exposure comprise several different approaches.

Firstly, reverse metabolism, which involves the chemical reduction of the dozens of urinary metabolites back to the parent PAH. This method, developed by Konieczny and Harvey, ${ }^{5}$ and applied by others both reduces the number of species to be 
assayed and increases sensitivity. ${ }^{6-10}$ Secondly, urinary mutagenic activity is used as an indicator of nonspecific mutagen presence. ${ }^{811}$ Although this method can detect large fluctuations in exposure, it is not very sensitive. Thirdly, one or more PAH metabolites are selected to represent total PAH. Sensitivity of this approach is enhanced by selecting the most abundant metabolite of the most prevalent PAH. Grimmer et al used this approach with metabolites of a few prominent PAHs. ${ }^{12}$ Jongeneelen et al used one PAH, pyrene, and its metabolite 1-OHPY. ${ }^{1}$ Fourthly, detection of PAH DNA adducts uses highly sensitive methods including immunoassay, enzyme linked immunosorbent assays (ELISA), and ${ }^{32} \mathrm{P}$ postlabelling. ${ }^{1314}$

Of these approaches, the third, employing the pyrene metabolite 1-OHPY, has shown promising results. The use of 1-OHPY as a biomarker of exposure was developed through an animal study, ${ }^{15}$ an in vitro study using human liver preparation, ${ }^{16}$ and ultimately application to occupationally exposed and therapeutically treated human subjects. ${ }^{1-31718}$ As a biomarker of PAH exposure, 1-OHPY has the following advantages:

(1) The analytical method for detecting 1-OHPY in urine (reverse phase high performance liquid chromatography (HPLC) with fluorescent detection) is sensitive and is characterised by high analytical recoveries. ${ }^{19}$ Also, 1-OHPY has been found to be stable and has only one known precursor, pyrene. ${ }^{20}$

(2) The parent compound pyrene is a relatively large proportion of the higher molecular weight occupational $^{1}$ and environmental airborne $\mathrm{PAHs}^{21}$ and is found in high proportions within the diet. Of 13 PAHs analysed in a duplicate plate survey, Vaessen et al reported that pyrene made up $23 \%$ of the median daily intake of total PAH. ${ }^{22}$ The relatively high pyrene:PAH ratio for exposure is further established by the identification of pyrene as the largest fraction $(23 \%)$ of PAH in human fat for eight different PAHs assayed. ${ }^{23}$

(3) 1-Hydroxypyrene in urine is representative of pyrene and total PAH occupational air and dermal exposure. Tolos et al reported that occupational inhalation exposure to total PAHs was significantly correlated (Spearman $r=0.62 ; p=0.006$ ) with 1 OHPY in urine. ${ }^{4}$ Among paving workers, urine 1OHPY was correlated with pyrene dermal exposure from coal tar derived road tars on the wrist (Spearman rank: $r=0.36(p<0.05))$ and hands $(r=0.63$ $(\mathrm{p}<0.01)) .^{3}$

(4) 1-Hydroxypyrene in urine is a good indicator for mutagenic activity as shown in animals $(r=0.93)$ and in in vitro assays with human hepatic preparations $(r=0.95-0.97$ for three donors $){ }^{24}$

\section{Methods}

STUDY DESIGN

Two experiments, each six days in duration, were conducted during 16-22 and 24-30 September 1988. Dietary exposure was controlled with a specially prepared meal high in PAHs preceded and followed by a three day period during which the diet was specifically designed to minimise exposure to PAHs. Because inhalation is a potentially significant route of exposure to PAHs, 24 hour personal air sampling was conducted. The same experimental protocols were used for both experiments but the ambient personal air concentrations were different for each and necessitated identification as experiments 1 and 2 . Urine was sampled at eight hour intervals in each experiment.

Urine was assayed for 1-OHPY concentration whereas external exposure was evaluated by determining benzo(a)pyrene $(\mathrm{BaP})$ concentrations in air and food. This dichotomous approach was necessary due to limitations of the analytical instrumentation (thin layer chromatography (TLC)) for the separation of pyrene and sampling limitations for collection of the vapour phase of pyrene. By contrast, $\mathrm{BaP}$ is discretely separated by TLC and exists almost exclusively in the particulate phase. This makes it routinely measurable in each medium.

\section{STUDY PARTICIPANTS}

Five volunteers from the Department of Environmental and Community Medicine participated in the study. All were men and non-smokers. Their ages ranged from 21 to 41 and none were involved in therapeutic (for example, coal tar shampoos or ointments) or occupational exposures to PAHs. Three of the subjects participated in the two experiments and two subjects participated in only one experiment, giving four participants in each experiment.

\section{MINIMUM PAH EXPOSURE MEALS}

To obtain periods of minimal dietary PAH exposure before and after the high PAH meal, participants were asked to select foods and preparation techniques that would give a low PAH diet. This selection was based on guidelines (summarised in table 1) developed from published reports of $\mathrm{BaP}$ concentrations in various foods and cooking methods that enhance PAH formation. ${ }^{25-28}$

THE HIGH PAH MEAL

Fresh high fat ground beef was purchased and cooked over a combination wood and charcoal flame in an outdoor covered grill to produce a high $\mathrm{PAH}$ meal. 25293031 The high fat concentrations in the ground beef enhances PAH formation during cooking by melting, pyrolysing, and then depositing on the meat. ${ }^{31}$ Thin patties were used to provide maximum surface contact with the heat, flame, and smoke. The patties were cooked for roughly 10 minutes a side until very well done. A lid was placed on the grill to maximise exposure of the meat to the smoke. After cooking, the patties were combined and 
Table 1 Dietary instructions to minimise BaP dietary exposure

\begin{tabular}{ll}
\hline Low PAH content & High PAH content \\
\hline Pasta with tomato sauce & Vegetable oils \\
Cereal & Fats and shortenings \\
Fruit & Fried foods \\
Milk & Shellfish \\
Vegetables: peas, corn, beans & Smoked meats \\
Rice & Broiled meats \\
Cheese & Roasted coffee \\
Bread & Tea \\
Apples & Leafy green vegetables \\
Lentils & Grilled foods \\
Tomatoes & Toasted bread \\
Orange juice & Mayonnaise \\
Hotdogs & Potato chips \\
Oatmeal & \\
Soups & \\
\hline
\end{tabular}

homogenised in a food processor, divided into $250 \mathrm{~g}$ portions, frozen, and stored.

At the time of the high PAH meal the ground beef was thawed and reheated, using spices and sauces prepared to taste. Flavouring strategies included Hamburger Helper, ketchup, and tomato sauce. The meal was eaten with crackers, pasta, or bread over a 30 minute period. No other solid foods were eaten during the six hours before the high PAH meal.

\section{SAMPLING}

Personal air

Inhalation exposure to $\mathrm{BaP}$ was assessed on 24 hour personal air samples collected with an MS and T personal impactor $\left(d_{50}=10 \mu \mathrm{m}\right)$. A PM-10 sampler intercomparison verified the collection efficiency of the impactor. ${ }^{32}$ The impactor was loaded with a Gelman Type AE $25 \mathrm{~mm}$ glass fibre filter. A Dupont Model P4LA high flow personal pump was attached to the impactor and operated at $4 \mathrm{l} / \mathrm{min}$. Participants were asked to wear the sampler throughout the day and when this was not possible (for instance, during aerobic exercises or in the shower) to place it nearby. At night the sampler operated on a bed stand.

\section{Diet}

A one quarter portion of all non-liquidised foods eaten during the experiment was obtained from each meal. Samples were collected daily and placed in an aluminum container, sealed, and frozen $\left(-20^{\circ} \mathrm{C}\right)$. The samples were thawed, weighed, combined according to pre and post-high PAH meal periods, homogenised in a food processor, and stored frozen until analysed. The charcoal broiled ground beef used as the primary basis of the high PAH meal originated from the same batch for each participant.

\section{Urine}

Throughout each experiment 24 hour urine samples were collected for six days; however, for some participants it was not possible to collect all voids. Each participant was responsible for providing their daily voids as three eight hour composite samplesnamely, evening (1600-2400); night (2400-800); day (800-1600).

A sample day started with the first evening void and ended at 1600 on the next day. Because it was not practical to strictly regulate void times, in practice the sample periods may have deviated by one to two hours. Voids were collected in brown polyethylene $500 \mathrm{ml}$ containers (Sarstedt Inc, Princeton, NJ) and labelled with an identification number, the date, and the time.

\section{ANALYTICAL METHODS AND QUALITY ASSURANCE $B a P$ in air samples}

Personal air samples were analysed by the method described by Swanson et al..$^{33}$ Filters were extracted whole in $1 \mathrm{ml}$ high performance liquid chromatography (HPLC) grade cyclohexane for 20 minutes at $78-80^{\circ} \mathrm{C}$ with ultrasonication and then allowed to stand for one hour. Each extract was spotted $(250 \mu \mathrm{l}$ aliquot) in duplicate on $20 \%$ acetylated cellulose silica plates and developed in the dark in 2:1 ethanol: dichloromethane for thin layer chromatographic separation. After air drying the plates were read with a Perkin-Elmer MPF44B plate scanning spectrofluorimeter at $387 \mathrm{~nm}$ excitation and $428 \mathrm{~nm}$ emission. Peak areas were integrated with a Spectrophysics 4000 integrator.

Quality assurance was provided with NIST Standard SRM 1647 urban particulate certified 2.9 (SD 0.5$) \mu \mathrm{g} / \mathrm{g}$. This standard was analysed in triplicate and gave a precision of $20 \%$. Analyses of filters $(n=9)$ spiked with $\mathrm{BaP}$ showed a mean recovery of $104 \cdot 3$ (SD $14 \cdot 7 \%$ ). The limit of detection for the personal air filters is $0.05 \mathrm{ng} /$ filter. All field blanks were evaluated as non-detectable and all samples were above the limit of detection. ${ }^{34}$

\section{BaP in food samples}

Samples were analysed by Greenberg et al ${ }^{35}$ according to the method developed by Howard et $a l^{36}$ and Xia et al. ${ }^{37}$ Digestion and saponification of a $100 \mathrm{~g}$ aliquot of the aggregated food sample was completed with $7 \%$ potassium hydroxide in absolute ethanol $(200 \mathrm{ml})$ with stirring and reflux for two hours. The liquid portion was decanted into a separatory funnel and the remaining residual material washed with three $50 \mathrm{ml}$ portions of isooctane. The wash solution was used to extract the decanted ethanol solution. The ethanol solution was further extracted with two $60 \mathrm{ml}$ portions of isooctane. The extract solutions were combined and washed repeatedly with warm $\left(60^{\circ} \mathrm{C}\right)$ water until the isooctane solution was clear. If an emulsion existed, $20-30 \mathrm{ml}$ of saturated $\mathrm{NaCl}$ was added. Residual water was removed from the isooctane extract. The extract was passed through a treated and tested fluorosil column followed by three $60 \mathrm{ml}$ portions of benzene and the eluate was collected and rotoevaporated to $5 \mathrm{ml}$. Cyclohexane 
$(10 \mathrm{ml})$ was added and the solution was evaporated to about $2 \mathrm{ml}$ and transferred to a vial with three $2 \mathrm{ml}$ washes of the flask. The solution was blown down to $1 \mathrm{ml}$ under nitrogen and separated and detected as described above.

Recovery was evaluated by analysing spiked samples as no NIST standards were available for $\mathrm{BaP}$ in food. $\mathrm{BaP}$ was injected into a broiled hamburger and two food samples to give a concentration comparable with reported concentrations. An average recovery of 82.4 (SD $6.4 \%$ ) was determined for four assays. The mean precision was 19 (SD $15.4 \%$ ) for 14 duplicate samples. ${ }^{34}$

\section{1-Hydroxypyrene in urine}

The analytical method employed for determining 1hydroxypyrene was developed by Keimig et $\mathrm{al}^{15}$ and applied to human subjects by Jongeneelen et al. ${ }^{19}$ The method consisted of enzymatic hydrolysis, sample extraction, and purification with a $\mathrm{C}_{18}$ cartridge, reversed phase HPLC for separation, and detection with spectrofluorescence. Only HPLC grade solvents were used and precautions were taken throughout to protect the samples from exposure to light.

Samples were stored in a freezer at $-20^{\circ} \mathrm{C}$ in opaque plastic containers and prepared for analysis by slowly thawing, stirring, and delivering a $55 \mathrm{ml}$ aliquot to a pyrex Erlenmeyer flask. Urine samples were adjusted to $\mathrm{pH} 5.0$ with concentrated hydrochloric acid and buffered with $5 \mathrm{ml}$ of acetate buffer, pH 5.0.

Enzymatic hydrolysis of the glucuronide and sulphate 1-OHPY conjugates was accomplished with $\beta$ glucuronidase/sulphatase, type $\mathrm{H}-1$, from Helix pomatia (product no G-07511) obtained form Sigma Chemical Co, St Louis, Missouri. This enzyme has an activity of 400000 units $/ \mathrm{g}$. (A unit is defined as the amount of enzyme that will liberate $1.0 \mu \mathrm{g}$ of phenolphthalein from phenolphthalein glucuronide per hour at $\mathrm{pH} 5.0$ and $37^{\circ} \mathrm{C}$ ). The enzyme also has sulphatase activity of 20800 units/g of solid (one unit will hydrolyse $1.0 \mu \mathrm{mol}$ of $\mathrm{p}$-nitrocatechol sulphate per hour at $\mathrm{pH} 5.0$ and $37^{\circ} \mathrm{C}$ ). At least $15 \mathrm{mg}$ of the solid was added to $55 \mathrm{ml}$ of sample. The enzyme activated sample was placed in a constant temperature $\left(37^{\circ} \mathrm{C}\right)$ rotary shaker water bath for more than 12 hours.

The polar urinary metabolites, including 1OHPY, were extracted by passing the sample through a reversed phase $C_{18}$ Sep-Pack cartridge (Waters, Milford, Massachusetts) with a $60 \mathrm{ml}$ syringe. The cartridge was first primed with $5 \mathrm{ml}$ methanol then $10 \mathrm{ml}$ of water. The sample was passed through the cartridge over a period of 30 minutes or more. The extracted metabolites were eluted from the cartridge with $10 \mathrm{ml}$ methanol after a wash with 5 $\mathrm{ml}$ water. To further concentrate the eluate the methanol solution was evaporated down to $2.5 \mathrm{ml}$ in a $60^{\circ} \mathrm{C}$ water bath with air gently blown over the sample. The concentrated solution was passed through a $0.20 \mu \mathrm{m} 25 \mathrm{~mm}$ syringe filter into an autosampler amber vial and sealed with a Teflon septum for HPLC analysis.

Separation of the sample constituents was accomplished with reversed phase HPLC. A Water's $600 \mathrm{E}$ multi-solvent delivery system equipped with a 712 WISP autosampler, and a MAXIMA software computer interface was used for data acquisition. The system delivered a methanol:water linear gradient $(0.8 \mathrm{ml} / \mathrm{min})$ starting at $46: 54$ for 5 minutes to $94: 6$ over 35 minutes holding for 10 minutes. Methanol and water reservoirs were purged with helium before and during sample runs. $\mathrm{AC}_{18}$ reverse phase $150 \times 4$ $\mathrm{mm}$ column with $5 \mu \mathrm{m}$ packing equipped with a guard column (Separations Group, Hesperia, CA) was maintained at $40^{\circ} \mathrm{C}$ in a column oven. A Perkin Elmer $650 \mathrm{~S}$ fluorescence detector with a flow through microcuvette was used to detect 1-OHPY. The fluorimeter was set for an excitation wavelength of $242 \mathrm{~nm}$ and an emission of $388 \mathrm{~nm}$ with both slits adjusted to $5 \mathrm{~nm}$. Peak area was used for quantification. A volume of $30 \mu \mathrm{l}$ was injected on to the column.

1-Hydroxypyrene standards were prepared from material reported to be $99 \%$ pure by HPLC and ultraviolet analysis (Chemsyn Science Laboratories) in methanol at concentrations of $0.538,1.07,3.23$, $6.46,10 \cdot 78$, and $16.93 \mathrm{ng} / \mathrm{ml}$. Only low energy red lights were used to weigh and prepare standards, which were then stored refrigerated in amber glass. A linear calibration curve $\left(\mathrm{r}^{2}>0.99\right)$ was obtained and the intercept was not significantly different from zero $(p=0.05)$. A limit of detection of $0.023 \mathrm{ng} / \mathrm{ml}$ was established.

A recovery study was conducted at four concentrations on duplicate spiked samples. A large urine sample composite was mixed and split into nine $55 \mathrm{ml}$ sample aliquots. One $\mathrm{ml}$ of standard solution at concentrations of $0,3 \cdot 23,6 \cdot 46$, and $10 \cdot 78 \mathrm{ng} / \mathrm{ml}$ was added to each sample. The first three were prepared in duplicate and the fourth was prepared in triplicate. Recoveries for the concentrations greater than zero were $100 \cdot 5$ (SD 24.1\%), 94.6 (SD 2.2\%), and 93.7 (SD $2.5 \%$ ) respectively, which exceeded the average recovery of $85 \%$ reported by Jongeneelen et al. ${ }^{19}$

A test was conducted to ensure that the $\beta$ glucuronidase was being added to the sample in excess. A urine sample previously determined to contain high concentrations of 1-OHPY was treated with varying amounts of enzyme. For samples with $\geqslant 6.3 \mathrm{mg}$ of enzyme there was no difference in the 1OHPY concentration; this indicates that the $15 \mathrm{mg}$ used in the protocol was in excess (table 2).

Precision of the analytical procedure was estimated based on duplicate analysis of 37 samples $(24 \%$ of the number analysed). The coefficient of variation of the 
Table 2 Enzyme dependent determination of urinary 1$O H P Y$

\begin{tabular}{lc}
\hline Enzyme added $m g$ & Concentration $n g / m l$ \\
\hline 0 & $4 \cdot 8$ \\
$6 \cdot 3$ & $57 \cdot 2$ \\
11.2 & $53 \cdot 6$ \\
$15 \cdot 5$ & $55 \cdot 7$ \\
21.0 & $53 \cdot 4$ \\
\hline
\end{tabular}

duplicate analysis ranged from 1.5 to $61 \%$ with a mean of $16 \cdot 2 \%$. Jongeneelen et al reported a coefficient of variation of $12 \cdot 6 \%(n=24) .{ }^{19}$

\section{CHANGE IN DOSE COMPARED WITH CHANGE IN}

\section{ELIMINATION}

The effect of the change in ingested dose from the minimum exposure to PAH (MEP) meals to the high-PAH meal on 1-OHPY urine elimination was investigated by a comparison of the respective ratios. The high PAH meal dose is simply the product of the $\mathrm{BaP}$ concentration of the meal and the mass eaten. The average ingested MEP dose was determined as the product of the mean pre and post-high PAH meal $\mathrm{BaP}$ concentration (weighted for mass of the sample) and the estimated mass for an average meal. The meal mass was determined from an EPA estimate of $2590 \mathrm{~g}$ ingested assuming that the mass is equally portioned over three meals a day. ${ }^{38}$ The calculation of the MEP average ingested dose is as follows:

$$
\frac{\left(C_{\text {pre }} \times M_{\text {pre }}\right)+\left(C_{\text {post }} \times M_{\text {post }}\right)}{\left(M_{\text {pre }}+M_{\text {post }}\right)} \times M_{\text {meal }}=D_{\text {meal }}
$$

Where:

$\mathrm{C}_{\text {pre }}=$ dietary BaP concentration in the pre meal sample (ng/kg).

$M_{\text {pre }}=$ mass of the pre sample $(\mathrm{kg})$.

$\mathrm{C}_{\text {post }}=$ dietary $\mathrm{BaP}$ concentration of the post sample (ng/g).

$M_{\text {post }}=$ mass of the post dose sample $(\mathrm{g})$.

$M_{\text {meal }}=$ mass of average meal assuming $2590 \mathrm{~g} /$ day divided by three meals a day ( $863 \mathrm{~g}$ ).

$\mathrm{D}_{\text {meal }}=$ MEP average ingested meal dose (ng/meal).

The 1-OHPY elimination ratio was calculated for the corresponding dietary dose ratio using the 1OHPY eliminated from the high PAH meal and from the average MEP meal. The amount of 1-OHPY eliminated from the high PAH meal is determined by integrating the function obtained for a kinetics model from time 0 to $6 \times t_{1 / 2}$. Six half lives represents $92 \%$ of the total amount eliminated. The median elimination rate during the MEP period before the high $\mathrm{PAH}$ meal is considered background and is not included in the determination of the area under the elimination rate $v$ time curve (AUC). The 1-OHPY elimination for the MEP was determined to be the amount eliminated over the period from 0 to $6 \times t_{1 / 2}$ using the median MEP elimination rate.

\section{KINETIC MODEL}

The pattern of urinary 1-OHPY elimination after the high PAH meal was analysed using a kinetics simulation software, PCNONLIN, version 3.0 (Statistical Consultants Inc, Lexington, KT). Non-linear regression analysis was used to develop a biexponential model assuming 1st order appearance and disappearance of 1-OHPY in urine:

$$
\begin{aligned}
& \mathrm{U}_{\mathrm{R}}(\mathrm{t})=\mathrm{A}\left(\mathrm{e}^{-\mathrm{kdt}}-\mathrm{e}^{-\mathrm{kat}}\right)(2) \\
& \text { Where: } \\
& \mathrm{A}=\text { constant. } \\
& \mathrm{U}_{\mathrm{R}}=\text { the rate of urinary 1-OHPY elimination }
\end{aligned}
$$
as a function of time $(\mathrm{ng} / \mathrm{h})$;

$\mathrm{k}_{\mathrm{a}}=$ the $1 \mathrm{st}$ order rate constant for the appearance of 1-OHPY in the urine $\left(h^{-1}\right)$; and

$k_{d}=$ the 1st order rate constant for the disappearance of 1-OHPY from the urine $\left(h^{-1}\right)$.

PCNONLIN provided estimates for $\mathrm{A}$ and the rate constants $k_{\mathrm{a}}$ and $\mathrm{k}_{\mathrm{d}}$. From these estimates secondary parameters are readily determined:

$t_{1 / 2}=\ln 2 / k_{d}$ : the half life for the disappearance of 1 -OHPY in urine $(h)$.

$\mathrm{AUC}=\mathrm{A}\left(\mathrm{e}^{-\mathrm{kdt}}-\mathrm{e}^{-\mathrm{kat}}\right)$ : the area under the elimination rate $v$ time curve (ng).

$\mathrm{t}_{\max }=\ln \left(\mathrm{k}_{\mathrm{a}} / \mathrm{k}_{\mathrm{d}}\right) /\left(\mathrm{k}_{\mathrm{a}} / \mathrm{k}_{\mathrm{d}}\right)$ : time at maximal elimination rate (h).

$R_{\max }=$ Rate at $t_{\max }$ : maximal elimination rate (ng/h).

When the high PAH meal occurred during the middle of a urine sample collection period, estimates were made of the portion of the 1-OHPY attributable to the meal. The amount of 1-OHPY eliminated before the high $\mathrm{PAH}$ meal was determined as the arithmetic mean of the elimination rate before the high PAH meal multiplied by the time interval from the start of the experiment to the high PAH meal. Subtracting this amount from the total elimination and dividing by the time interval from the high PAH meal to the end of the experiment gave the mass attributable to the high PAH meal. Elimination rates for 1-OHPY after the high PAH meal were corrected for background by subtracting the pre high PAH meal elimination rate.

\section{Results}

\section{DIETARY BAP EXPOSURES AND DOSE}

The dietary samples for the minimum exposure period were collected and analysed for two intervals-namely, pre and post-high PAH meal. A separate analysis was completed for the high PAH meal. The pre-high PAH meal included food eaten during the three and two days before the high $\mathrm{PAH}$ meal for experiments 1 and 2, respectively. On the assumption that all meals were sampled and three meals were eaten each day, a maximum of 15 , nine, 
Table 3 Minimum exposure period dietary $\mathrm{BaP}$ concentration and estimated dose

\begin{tabular}{lllclr}
\hline PID & & $\begin{array}{l}\text { No of } \\
\text { meals }\end{array}$ & $\begin{array}{l}\text { Sample } \\
\text { mass }\end{array}$ & $\begin{array}{l}\text { BaP } \\
\text { conc } \\
\text { ng/kg }\end{array}$ & $\begin{array}{l}\text { BaP } \\
\text { dose } \\
\text { ng/day }\end{array}$ \\
\hline 1001 & Pre & 15 & 943 & 52 & $134 \cdot 7$ \\
& Post & 14 & 1155 & 55 & $142 \cdot 5$ \\
1003 & Pre & 7 & 550 & 32 & $81 \cdot 9$ \\
& Post & 14 & 1428 & 40 & $103 \cdot 6$ \\
1004 & Pre & 13 & 1840 & 19 & $49 \cdot 2$ \\
& Post & 9 & 1412 & 35 & $90 \cdot 6$ \\
1005 & Pre & 5 & 370 & 75 & $194 \cdot 1$ \\
& Post & 1 & 172 & 12 & $31 \cdot 8$ \\
1006 & Pre & 8 & 510 & 41 & $106 \cdot 2$ \\
& Post & 2 & 274 & 78 & $201 \cdot 5$ \\
\hline
\end{tabular}

and six meals could be sampled for persons participating in both experiments, in experiment 1 , or in experiment 2. The post-high PAH period consisted of 14 meals (seven in each experiment) covering four and two thirds days.

Table 3 shows the concentration of $\mathrm{BaP}$ in the food samples and the estimated ingested doses for the MEPs. The mass weighted median concentration for the MEP meals was $38 \mathrm{ng} / \mathrm{kg}$ (range $12-78 \mathrm{ng} / \mathrm{kg}$ ).

The high PAH meal concentration was $22450 \mathrm{ng} /$ $\mathrm{kg}$ representing nearly a 600 -fold increase in the dietary $\mathrm{BaP}$ concentration from the median MEP value. Assuming that the entire high PAH meal was ingested, a BaP dose of $5.6 \mu \mathrm{g}$ was delivered to the gut. The entire high PAH meal was eaten in six of eight cases (table 4).

\section{PERSONAL AIR BaP EXPOSURES AND DOSE}

Personal air sampling was conducted to evaluate daily $\mathrm{BaP}$ concentrations in personal air. The applied inhaled dose was calculated from the personal concentration values by assuming a respiratory rate of $22 \cdot 7 \mathrm{~m}^{3} /$ day. Inhaled dose values were within a narrow range and were orders of magnitude smaller than the ingested $\mathrm{BaP}$ dose (table 5).

\section{URINARY 1-HYDROXYPYRENE ELIMINATION RATE}

Urine sampling and analysis were conducted to measure 1-OHPY concentrations during the two experiments. Urine voids were collected 24 hours a day, but not all participants provided complete samples. The completeness of a sample was defined as the per cent of the total experiment time covered by the collected voids. A complete set of urine samples would include all voids made over the sampling period. The time interval for missing voids was estimated using the time and volume of the collected voids. Table 6 summarises the urine sampling results by pre and post-high PAH meal periods with the post-high PAH meal period partitioned to differentiate the peak elimination period.

The completeness of the urine sampling ranged from 53 to $100 \%$. During the critical "peak" period after the high PAH meal, collection averaged $87 \%$ (range 73-100\%); person identification (PID) 1001 provided a complete urine sampling set by providing all voids collected over the 12 days covering the two experiments.

The time series of urinary 1-OHPY elimination for each PID began at 1600 with the evening sample (when available). A value was plotted at the midpoint of the interval over which the sample was collected. The peak 1-OHPY elimination rate coincided with the period after the high PAH meal for all cases. Figure 1 shows the results for PID 1001.

Figure 2 shows the rate of 1-OHPY elimination during the MEP for each participant. Analysis of variance indicated significant differences between the means for the five participants. The Shapiro Wilks test was significant $(p=0.05)$ for the log transformed data indicating that the elimination rates were

Table 4 The delivered dose of $B a P$ resulting from the high-PAH meal

\begin{tabular}{|c|c|c|c|c|c|c|c|}
\hline \multicolumn{4}{|c|}{ Experiment 1 high $P A H$ meal } & \multicolumn{4}{|c|}{ Experiment 2 high $P A H$ meal } \\
\hline$P I D$ & Day & Mass $g$ & Dose $\mu g /$ meal & $P I D$ & Day & Mass $g$ & Dose $\mu \mathrm{g} / \mathrm{meal}$ \\
\hline $\begin{array}{l}1001 \\
1003 \\
1004 \\
1005\end{array}$ & $\begin{array}{l}4 \\
4 \\
4 \\
4\end{array}$ & $\begin{array}{r}197 \\
250 \\
90 \\
250\end{array}$ & $\begin{array}{l}4 \cdot 42 \\
5 \cdot 61 \\
2 \cdot 27 \\
5 \cdot 61\end{array}$ & $\begin{array}{l}1001 \\
1003 \\
1004 \\
1006\end{array}$ & $\begin{array}{l}12 \\
12 \\
12 \\
11\end{array}$ & $\begin{array}{l}250 \\
250 \\
250 \\
250\end{array}$ & $\begin{array}{l}5 \cdot 61 \\
5 \cdot 61 \\
5 \cdot 61 \\
5 \cdot 61\end{array}$ \\
\hline
\end{tabular}

Table 5 Personal air BaP concentration and applied dose

\begin{tabular}{llllll}
\hline & & & \multicolumn{2}{c}{ Applied dose } \\
\cline { 4 - 6 } PID & No of days & Mean sample $h$ & Median conc $n g / m^{3}$ & Median ng/day & Range ng/day \\
\hline 1001 & 10 & $18 \cdot 7$ & $0 \cdot 20$ & $3 \cdot 9$ & $2 \cdot 3-8 \cdot 5$ \\
1003 & 7 & $20 \cdot 0$ & $0 \cdot 12$ & $2 \cdot 2$ & $0 \cdot 6-7 \cdot 4$ \\
1004 & 12 & $20 \cdot 2$ & $0 \cdot 12$ & $1 \cdot 1$ & $0 \cdot 1-5 \cdot 0$ \\
1005 & 6 & $22 \cdot 1$ & $0 \cdot 06-1 \cdot 8$ & $0 \cdot 7-1 \cdot 5$ \\
1006 & 5 & $23 \cdot 8$ & $0 \cdot 08$ & $1 \cdot 2$ & 0 \\
\hline
\end{tabular}


Table 6 Urine sampling results

\begin{tabular}{|c|c|c|c|c|c|c|c|c|c|c|}
\hline \multirow[b]{3}{*}{$P I D$} & \multirow[b]{3}{*}{$\operatorname{Exp}$} & \multirow{2}{*}{\multicolumn{3}{|c|}{ Pre period }} & \multicolumn{6}{|c|}{ Post period } \\
\hline & & & & & \multicolumn{3}{|l|}{ Peak } & \multicolumn{3}{|c|}{ Post peak } \\
\hline & & Voll & Void $h$ & $C C \%$ & Voll & Void $h$ & $C C \%$ & Voll & Void $h$ & $C C \%$ \\
\hline $\begin{array}{l}1001 \\
1001\end{array}$ & $\begin{array}{l}1 \\
2\end{array}$ & $\begin{array}{l}3 \cdot 85 \\
4 \cdot 39\end{array}$ & $\begin{array}{l}65 \\
70\end{array}$ & $\begin{array}{l}100 \\
100\end{array}$ & $\begin{array}{l}1.64 \\
2.53\end{array}$ & $\begin{array}{l}34 \\
33\end{array}$ & $\begin{array}{l}100 \\
100\end{array}$ & $\begin{array}{l}1.29 \\
3.65\end{array}$ & $\begin{array}{l}33.5 \\
33.8\end{array}$ & $\begin{array}{l}100 \\
100\end{array}$ \\
\hline $\begin{array}{l}1003 \\
1003\end{array}$ & $\begin{array}{l}1 \\
2\end{array}$ & $\begin{array}{l}3.99 \\
2.91\end{array}$ & $\begin{array}{l}56 \\
34\end{array}$ & $\begin{array}{l}87 \\
53\end{array}$ & $\begin{array}{l}3.00 \\
1.68\end{array}$ & $\begin{array}{l}31 \\
33\end{array}$ & $\begin{array}{l}87 \\
89\end{array}$ & $\begin{array}{l}1.58 \\
2.29\end{array}$ & $\begin{array}{l}26 \cdot 8 \\
23 \cdot 0\end{array}$ & $\begin{array}{l}74 \\
87\end{array}$ \\
\hline $\begin{array}{l}1004 \\
1004\end{array}$ & $\begin{array}{l}1 \\
2\end{array}$ & $\begin{array}{l}3.57 \\
2.60\end{array}$ & $\begin{array}{l}58 \\
42\end{array}$ & $\begin{array}{l}77 \\
60\end{array}$ & $\begin{array}{l}3.04 \\
2.09\end{array}$ & $\begin{array}{l}31 \\
25\end{array}$ & $\begin{array}{l}73 \\
68\end{array}$ & $\begin{array}{l}2.38 \\
1.31\end{array}$ & $\begin{array}{l}22 \cdot 3 \\
22 \cdot 6\end{array}$ & $\begin{array}{l}88 \\
88\end{array}$ \\
\hline 1005 & 1 & $2 \cdot 50$ & 63 & 82 & 1.25 & 30 & 88 & 0.63 & $23 \cdot 0$ & 76 \\
\hline 1006 & 2 & 1.98 & 46 & 75 & $1 \cdot 37$ & 26 & 91 & 1.74 & $22 \cdot 8$ & 95 \\
\hline
\end{tabular}

Collection completion (CC) is the \% urine collection relative to the elapsed time. A CC of $100 \%$ indicates that urine samples have been collected over the entire duration of the elapsed time for that period. The first of these samples was a $24 \mathrm{~h}$ composite.

$\log$ normally distributed. The overall median for the 89 collected samples was $7 \cdot 0 \mathrm{ng} / \mathrm{h}$ with $75 \%$ and $25 \%$ quantiles of 12.95 and $4.25 \mathrm{ng} / \mathrm{h}$. In this limited data set, no consistent pattern existed in the rate of 1OHPY elimination according to the time of daythat is, diurnal variations were not found.

\section{KINETIC PARAMETER ESTIMATES}

A bi-exponential equation (2) was used to model the elimination rate data that followed the high PAH meal. Estimates of primary $\left(k_{\mathrm{a}}\right.$ and $\left.k_{\mathrm{d}}\right)$ and secondary (AUC, $t_{1 / 2}, t_{\max }$, and $R_{\max }$ ) parameters were determined for each participant (table 7). Figure 3 shows the fitted model for PID 1001 (experiments 1 and 2). The half life for the disappearance of 1-OHPY from the urine ranged from $3 \cdot 10$ to 5.9 hours, with a mean of 4.4 hours. The extreme parameter estimates for PID 1003, experiment 2 were believed to have resulted from improper recording of one or more collected voids; therefore, estimates for this experiment have been excluded in the summary statistics. Although the decrease in AUC and $R_{\max }$ appropriately reflects the decrease in the delivered dose for PID 1001 (table

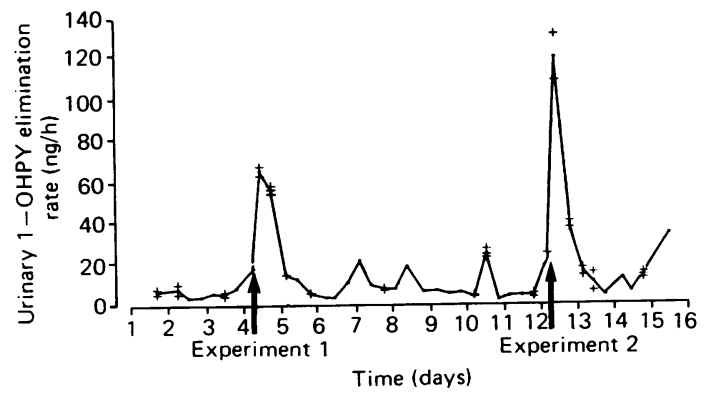

Figure 1 Urinary 1-hydroxypyrene elimination rate time series for PID 1001.
8), the inverse is seen for PID 1004. The incongruity for PID 1004 may be due to the incompleteness (73 and $68 \%$ for experiments 1 and 2 respectively) of urine collection during the peak periods.

\section{CHANGE IN 1-OHPY ELIMINATION CORRESPONDING TO CHANGE IN DIETARY DOSE}

The ingested dose ratio indicates a 100 to 250 -fold increase in the BaP dose from the average MEP meal to the high PAH meal (table 8). The elimination of 1OHPY from the high PAH meal was compared with elimination from the average MEP meal. The amount of 1-OHPY eliminated after the high PAH meal was determined by the area under the curve (AUC), evaluated from time 0 to $6 \times t_{1 / 2}$. Six half lives represented $92 \%$ of the total amount eliminated. The median elimination rate during the MEP period before the high PAH meal is considered background and is not included in the AUC calculation.



Figure 2 Elimination rate (ng/h of 1-OHPY during the minimum exposure period (MEP). 
Table 7 Urinary 1-hydroxypyrene elimination kinetic parameter estimates

\begin{tabular}{|c|c|c|c|c|c|c|c|}
\hline$P I D$ & $\operatorname{Exp}$ & $k_{a} h^{-I}$ & $k_{d} h^{-1}$ & $A U C n g$ & $t_{\max } h$ & $R_{\max } n g / h$ & $t_{1 / 2} h$ \\
\hline $\begin{array}{l}1001 \\
1001\end{array}$ & $\begin{array}{l}1 \\
2\end{array}$ & $\begin{array}{l}0 \cdot 18 \\
0 \cdot 19\end{array}$ & $\begin{array}{l}0.17 \\
0.19\end{array}$ & $\begin{array}{l}2006 \\
1367\end{array}$ & $\begin{array}{l}5 \cdot 7 \\
5 \cdot 2\end{array}$ & $\begin{array}{l}65 \\
97\end{array}$ & $\begin{array}{l}4.04 \\
3.60\end{array}$ \\
\hline $\begin{array}{l}1003 \\
1003\end{array}$ & $\begin{array}{l}1 \\
2\end{array}$ & $\begin{array}{l}0.14 \\
1.15\end{array}$ & $\begin{array}{l}0.14 \\
0.06\end{array}$ & $\begin{array}{l}2933 \\
1950\end{array}$ & $\begin{array}{l}7 \cdot 1 \\
2 \cdot 8\end{array}$ & $\begin{array}{l}151 \\
95\end{array}$ & $\begin{array}{r}4.94 \\
12.22\end{array}$ \\
\hline $\begin{array}{l}1004 \\
1004\end{array}$ & $\begin{array}{l}1 \\
2\end{array}$ & $\begin{array}{l}0.19 \\
0.12\end{array}$ & $\begin{array}{l}0.20 \\
0.12\end{array}$ & $\begin{array}{l}1523 \\
1390\end{array}$ & $\begin{array}{l}5 \cdot 2 \\
8 \cdot 4\end{array}$ & $\begin{array}{r}109 \\
60\end{array}$ & $\begin{array}{l}3.51 \\
5.92\end{array}$ \\
\hline 1005 & 1 & 0.22 & 0.22 & 2299 & 4.5 & 189 & $3 \cdot 10$ \\
\hline 1006 & 2 & $0 \cdot 13$ & $0 \cdot 12$ & 1890 & 8.0 & 87 & 5.59 \\
\hline
\end{tabular}

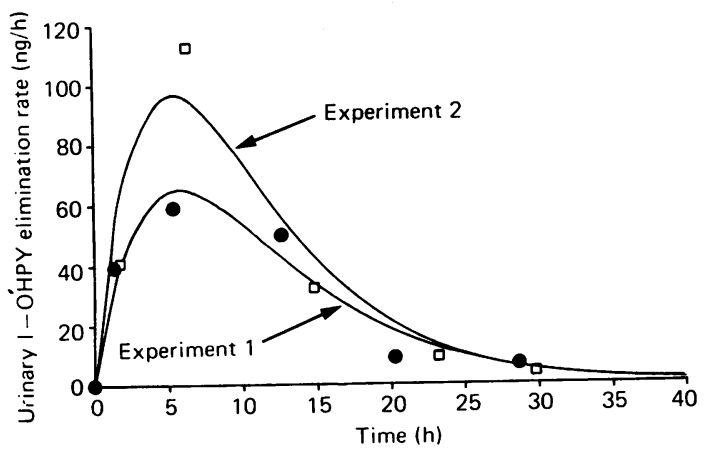

Figure 3 Biexponential model fitted to urinary 1hydroxypyrene elimination rate for PID 1001.

The elimination of 1-OHPY during the MEP was determined over the same period (six half lives) using the median MEP elimination rate. The ratio of 1OHPY urine elimination rate for the high PAH meal to the MEP had a mean of 8 and ranged from 4 to 12 (table 9).

The 100 to 250 -fold increase in the $\mathrm{BaP}$ ingested dose corresponded to an increase in the urinary 1OHPY elimination rate increase of 6 to 12 -fold.
There was no consistent relation between the magnitude of the dose ratio to the elimination rate ratio. The quotient of the ratios (1-OHPY/dose) suggests that a change in 1-OHPY corresponds to a 3 to $12 \%$ change in the ingested dose (table 10).

\section{Discussion}

Research has shown the utility of 1-OHPY as a biological marker of occupational dermal and inhalation exposures. ${ }^{1-4}$ Thus far, diet has not been considered in investigations relating exposure to the elimination of 1-OHPY, even though this route is potentially substantial and nearly unavoidable. Results presented here show the significance of dietary exposure on urinary 1-OHPY concentrations and define the time course from ingestion to the appearance of urinary 1-OHPY.

Dietary BaP exposures are reported to be similar to occupational inhalation exposures. The presence of PAHs in a wide variety of foods is well established..$^{25-28}$ Typical dietary $\mathrm{BaP}$ doses have been estimated by various investigators $\left(30-350 \mathrm{ng} /\right.$ day, ${ }^{39}$ $160-1600 \mathrm{ng} /$ day, ${ }^{40}$ median of $31 \mathrm{ng} /$ day, ${ }^{34}$ and median of $250 \mathrm{ng} / \mathrm{day}^{41}$ ). Results from the MEP diet showed that even when foods and preparation methods were used to minimise $\mathrm{PAH}$ concentrations,

Table 8 Comparison of ingested BaP dose from the MEP to the high PAH meal

\begin{tabular}{|c|c|c|c|c|c|c|c|c|c|}
\hline \multirow[b]{2}{*}{$P I D$} & \multirow[b]{2}{*}{ Period } & \multicolumn{5}{|c|}{ Minimum exposure period } & \multicolumn{2}{|c|}{ High PAH meal } & \multirow{2}{*}{$\begin{array}{l}\text { Ratio } \\
H-P A H \\
M E P\end{array}$} \\
\hline & & $\begin{array}{l}\text { No } \\
\text { meals }\end{array}$ & $\begin{array}{l}\text { Sample } \\
\text { mass } g\end{array}$ & $\begin{array}{l}\mathrm{BaP} \text { conc } \\
n g / \mathrm{kg}\end{array}$ & $\begin{array}{l}\text { Mean }{ }^{\star} \text { conc } \\
n g / k g\end{array}$ & $\begin{array}{l}\text { BaP dose } \\
\text { ng/meal }\end{array}$ & Mass $g$ & $\begin{array}{l}\text { BaP dose } \\
\text { ng/meal }\end{array}$ & \\
\hline \multirow[t]{2}{*}{1001} & Pre & 15 & 943 & 52 & 54 & 46 & 197 & 4423 & 95 \\
\hline & Post & 17 & 1155 & 55 & & & 250 & 5613 & 121 \\
\hline \multirow[t]{2}{*}{1003} & Pre & 7 & 550 & 32 & 38 & 33 & 250 & 5613 & 172 \\
\hline & Post & 17 & 1428 & 40 & & & 250 & 5613 & 172 \\
\hline \multirow{2}{*}{1004} & Pre & 13 & 1840 & 19 & 26 & 22 & 101 & 2267 & 101 \\
\hline & Post & 9 & 1412 & 35 & & & 250 & 5613 & 251 \\
\hline \multirow[t]{2}{*}{1005} & Pre & 5 & 370 & 75 & 55 & 47 & 250 & 5613 & 118 \\
\hline & Post & 1 & 172 & 12 & & & & & \\
\hline 1006 & $\begin{array}{l}\text { Pre } \\
\text { Post }\end{array}$ & $\begin{array}{l}8 \\
2\end{array}$ & $\begin{array}{l}510 \\
274\end{array}$ & $\begin{array}{l}41 \\
78\end{array}$ & 54 & 47 & 250 & 5613 & 121 \\
\hline
\end{tabular}

«The mean is weighted for the sample mass. 
Table 9 Comparison of urinary 1-OHPY elimination associated with the high-PAH meal and the MEP

\begin{tabular}{|c|c|c|c|c|c|}
\hline \multirow[b]{2}{*}{$P I D$} & \multirow[b]{2}{*}{$\operatorname{Exp}$} & \multirow{2}{*}{$\frac{\text { Peak elim }}{A U C^{\star} n g}$} & \multicolumn{2}{|c|}{ Minimum exposure period } & \multirow[b]{2}{*}{ Ratio high $P A H / M E P$} \\
\hline & & & Med elim rate $\mathrm{ng} / \mathrm{h}$ & $E \lim 6 \times t_{1 / 2} \dagger n g$ & \\
\hline $\begin{array}{l}1001 \\
1003 \\
1004 \\
1005 \\
1006\end{array}$ & $\begin{array}{l}1 \\
2 \\
1 \\
2 \\
1 \\
2 \\
1 \\
2\end{array}$ & $\begin{array}{r}933 \\
1257 \\
2697 \\
1794 \\
1392 \\
1281 \\
2114 \\
1743\end{array}$ & $\begin{array}{r}5 \cdot 5 \\
5 \cdot 5 \\
16 \cdot 3 \\
16 \cdot 3 \\
5 \cdot 3 \\
5 \cdot 3 \\
12 \cdot 0 \\
5 \cdot 4\end{array}$ & $\begin{array}{l}133.4 \\
118.9 \\
484.0 \\
\text { NA } \\
111 \cdot 6 \\
188 \cdot 1 \\
233.3 \\
181 \cdot 0\end{array}$ & $\begin{array}{c}7 \\
11 \\
6 \\
\text { NA } \\
12 \\
7 \\
10 \\
4\end{array}$ \\
\hline
\end{tabular}

$\star$ AUC evaluated from $\mathrm{t}=0$ to $\mathrm{t}=6 \times \mathrm{t}_{1 / 2}$.

tAmount of 1-OHPY eliminated at median MEP rate during a period of $6 \times t_{1 / 2}$.

Table 10 Comparison of ratios: change in dose and 1-OHPY elimination rate

\begin{tabular}{lllll}
\hline \multicolumn{5}{c}{ Ratio } \\
\cline { 3 - 5 } PID & Exp & $\begin{array}{l}\text { Change } \\
\text { dose }\end{array}$ & $\begin{array}{l}\text { Change } \\
1 \text {-OHPY }\end{array}$ & $\begin{array}{l}1 \text {-OHPY) } \\
\text { dose }(\%)\end{array}$ \\
\hline 1001 & 1 & 95 & 7 & $7 \cdot 4$ \\
1003 & 2 & 121 & 11 & $9 \cdot 1$ \\
1004 & 1 & 172 & 6 & $3 \cdot 5$ \\
1004 & 2 & 101 & 12 & $11 \cdot 9$ \\
1005 & 1 & 251 & 7 & $2 \cdot 8$ \\
1006 & 2 & 118 & 10 & $8 \cdot 5$ \\
\hline
\end{tabular}

the estimated median $\mathrm{BaP}$ dose was $105 \mathrm{ng} /$ day. An inhalation $\mathrm{BaP}$ dose range of $800-4500 \mathrm{ng} /$ day has been estimated from occupational concentrations ranging from $100-10000 \mathrm{ng} / \mathrm{m}^{3}$ and $1 \mathrm{~m}^{3} / \mathrm{h}$ inhaled for 8 hours. ${ }^{24} 4243$

The current study shows that dietary PAH exposure can be controlled by modifying diet and methods of food preparation. The median dietary $\mathrm{BaP}$ concentration of $38 \mathrm{ng} / \mathrm{kg}$ for the minimised exposure period was about half the median value of $71 \mathrm{ng} / \mathrm{kg}$ reported for a study conducted as a component of the Total Human Environmental Exposure Study (THEES). ${ }^{41}$ A strategy of controlling dietary PAH ingestion was also employed by Grimmer et al who reported $\mathrm{BaP}$ concentrations of 0.20 and $100 \mathrm{ng} /$ $\mathrm{kg}$ in PAH poor and rich diets respectively. ${ }^{44}$ Thus intake guidelines can be used to minimise ingestion as a route of exposure when examining other routes of exposure, such as by inhalation or through the skin.

The inhalation dose determined from 24 hour personal air samples was small relative to the ingested dose. The range in median inhaled dose for the five participants was 1.1 to $3.9 \mathrm{ng} /$ day whereas the ingested dose during the MEP ranged from 32 to 201 ng/day. For community exposures, it has been generally reported that the inhalation dose is less than that due to ingestion. ${ }^{344041}$ This result, however, is dependent upon individual activity patterns that are highly variable.
The method used to prepare the high PAH meal involved combustion sources of charcoal and wood, and was successful in creating high $\mathrm{BaP}$ concentrations in ground beef. The BaP concentration of 22.4 $\mu \mathrm{g} / \mathrm{kg}$ was similar to concentrations seen by other investigators when the same methods of cooking were used. Larsson et al reported food concentrations of $17.6 \mu \mathrm{g} / \mathrm{kg}$ when frankfurters were cooked over smouldering spruce or pine cones and a concentration of $212 \mu \mathrm{g} / \mathrm{kg}$ when the frankfurters were cooked within the flame of a $\log$ fire. ${ }^{29}$ Formation of $\mathrm{BaP}$ in grilled foods is believed to result from two processes: (1) the pyrolysis of the fat dripping on to the coals and the subsequent deposition of $\mathrm{BaP}$ containing particles on to the meat and (2) the incomplete combustion of the fuel and the deposition of particles on the food. ${ }^{29}{ }^{30}$ Therefore, BaP concentrations in grilled rich meats are characteristically higher relative to lean meats. ${ }^{31}$ Larsson et al showed that when cooked over a flame, formation of PAHs is dependent upon the position of the food relative to the flame such that maximum formation occurs when the meat is $6-7 \mathrm{~cm}$ from the flame. ${ }^{29}$

The current study showed that a 100 to 250 -fold increase in dietary $\mathrm{BaP}$ dose resulted in a four to 12fold increase in 1-OHPY elimination, indicating that the average change in 1-OHPY elimination was $6.6 \%$ of the change in ingested dose. A similar phenomenon was reported by Grimmer et al who compared PAH elimination using diets poor and rich in PAH and showed that a six to nine fold increase in ingested PAHs resulted in a two-fold increase in elimination of PAH metabolites. ${ }^{12}$ Therefore, the 1OHPY biomarker appears to be a less sensitive measure of exposure than external measures of exposure by at least an order of magnitude. This lack of sensitivity is likely to be due to the incomplete evaluation of elimination routes (biliary), and the incomplete evaluation of pyrene metabolites.

A mass balance assessment of the high PAH meal was conducted by comparing the amount of 1-OHPY eliminated in urine with a value predicted from the amount of $\mathrm{BaP}$ ingested. The pyrene concentration 
Table 11 Summary of reported urinary 1-hydroxypyrene levels



Results are converted into units of $\mu \mathrm{g} / 24 \mathrm{~h}$ by assuming that on average there is $11 \mathrm{mmol}$ creatinine/l urine and $15.9 \mathrm{mmol}$ of creatinine are eliminated $/ 24 h{ }^{49}$

$\mathrm{NA}=$ Not available; $\mathrm{Cr}=$ creatinine.

in the high PAH meal was estimated from reported pyrene : $\mathrm{BaP}$ ratios in foods. Concentration ratios of $4 \cdot 22,4 \cdot 36$, and $2 \cdot 25$ have been documented for frankfurters cooked over a log fire, charcoal-broiled steaks, and total diet samples respectively..$^{293045}$ Based on these data and the PAH high meal BaP dose value of $5.6 \mu \mathrm{g}$ the pyrene dose was estimated to be around $15-20 \mu \mathrm{g}$. Of the amount ingested $40 \%$ is assumed to have been absorbed in the gastrointestinal tract and of the amount absorbed, $29 \%$ to have been eliminated in the urine. ${ }^{46}{ }^{47} \mathrm{It}$ is further assumed that $46 \%$ of the total pyrene metabolites appears as $1-$ OHPY and conjugates. ${ }^{48} \mathrm{~W}$ ith these assumptions, it is estimated that from 0.8 to $1.07 \mu \mathrm{g}$ of pyrene would appear in the urine as 1-OHPY from the high PAH meal. This amount is roughly equal to the calculated amount of 1-OHPY eliminated from $t=0$ to $t=6$ $\times t_{1 / 2}$. The actual values ranged from 0.93 to $2.7 \mu \mathrm{g}$.

Researchers employing 1-OHPY as a biomarker have reported results in concentration units based on volume of creatinine, making comparisons with these data difficult. Rough comparisons can be made by converting volume or creatinine based units to $\mathrm{ng} /$ day if a standard daily volume and creatinine elimination rate is assumed. During the minimum exposure period the median urinary 1-OHPY elimination rate for the 88 samples from five persons was $168 \mathrm{ng} / 24 \mathrm{~h}$, with a range from 9.6 to $1046 \mathrm{ng} / 24 \mathrm{~h}$. This rate of elimination was exceeded by at least a factor of two among reported concentrations of comparable nonsmoking control groups (table 11). By contrast, the mean measured peak elimination rate among the seven person experiments reported here was $113 \mathrm{ng} /$ h. This degree of elimination scaled to a daily rate gives $2700 \mathrm{ng} /$ day, which is greater than the reported control values (including smoking controls) and about the same magnitude as that of the occupationally exposed cohorts. These data suggest that diet can influence elimination of 1-OHPY to an extent comparable with exposures due to occupational inhalation.

As a biomarker of environmental exposure, urinary 1-OHPY has potential due to the sensitivity of its detection and the prevalence of exposure to pyrene. 
It has been detected repeatedly among referent nonoccupationally exposed control groups. ${ }^{1412}$ Further research is required to ascertain the sensitivity with which the 1-OHPY biomarker responds to different degrees of exposure. Data reported here suggest that 1-OHPY may not be a sensitive indicator of exposures; it is likely that large variations in exposure will be required to detect changes in urinary 1OHPY concentrations. A further consideration is a recent animal study, which indicated that elimination of 1-OHPY was dependent upon the mode of administration. ${ }^{48}$

The kinetics of 1-OHPY elimination are of value in relating the exposure variables with biomarker concentrations, in developing sampling protocols, and in ensuring accurate interpretation of data. Results reported here indicate that after ingesting a high PAH meal, 1-OHPY is eliminated with a mean $t_{1 / 2}$ of 4.4 (SD 1.1) h and that there is a lag time to the occurrence of the maximal elimination rate of 6.3 $(S D 1.5) h$. These parameters of elimination suggest that a sampling strategy that relates an exposure at time $t=0$ to urine sampling from time $t=0$ to $24 \mathrm{~h}$ will capture most of the elimination attributable to that exposure.

\section{Conclusion}

Dietary exposures to PAHs can be controlled through diet and food preparation guidelines thereby providing a means to control the influence of this route of exposure.

Exposures to PAH through diet are substantial and can result in urinary elimination rates of 1-OHPY that are comparable with the occupational exposures.

Further research is required to ascertain the baseline elimination rate of 1-OHPY in the general population so that persons with raised concentrations can be identified and when necessary the source of exposure prevented.

Urinary 1-OHPY is eliminated after an ingested dose of PAHs, with a $t_{1 / 2}$ of 4.5 hours and a $t_{\max }$ of 6-7 hours. This suggests that to maximise the relation between exposure and urinary 1-OHPY, sampling strategies should be designed to collect urine within 24 hours after exposure.

Further research is required to assess the complete mass balance for exposure to pyrene (inhalation and ingestion) and elimination of 1-OHPY (urinary and biliary) and the effect that individual variability (sex, age, weight, activity, alcohol use, diet, etc) has on parameters of 1-OHPY elimination rate.

Urinary 1-OHPY concentration holds promise as an environmental marker of exposure due to the sensitivity of its detection; 1-OHPY elimination however appears to respond to only about $8 \%$ change in dietary exposure.

We gratefully recognise Arthur Greenberg, $\mathrm{PhD}$ for overseeing the analysis of $\mathrm{BaP}$ in dietary and air samples conducted in his laboratories. Mr Peter Creighton and $\mathrm{Mr}$ Che-han Hsu conducted the food sample preparation and analysis. Dr Jed Waldman and Ramana Dhara are acknowledged for their review and advice regarding the design and implementation of the experiments. We are grateful to the selfless volunteers who agreed to participate in these experiments and endure the inconvenience of the experimental requirements.

Mr Buckley received fellowship support from the Environmental and Occupational Health Science Institute during the period of this study. The research was supported by the New Jersey Department of Environmental Protection Agency, Division of Science and Research, and The NIEHS Center Grant No ES05022.

All subjects gave written informed consent for participation that was approved by the UMDNJ Institutional Review Board.

1 Jongeneelen FJ, Anzion RBM, Scheepers PTJ, et al. 1hydroxypyrene in urine as a biological indicator of exposure to polycyclic aromatic hydrocarbons in several work environments. Ann Occup Hyg 1988;32:35-43.

2 Jongeneelen FJ, Bos RP, Henderson PTh. Metabolites of polycyclic aromatic hydrocarbons in urine of exposed workers. Toxicology and Environmental Chemistry 1988;16: 295-307.

3 Jongeneelen FJ, Scheepers P, Groenendijk A, et al. Airborne concentrations, skin contamination, and urinary metabolite excretion of polycyclic aromatic hydrocarbons among paving workers exposed to coal tar derived road tars. Am Ind Hyg Assoc J 1988;49:600-7.

4 Tolos WP, Shaw PB, Lowry LK, MacKenzie BA, Deng J, Markel HL. 1-Pyrenol: a biomarker for occupational exposure to polycyclic aromatic hydrocarbons. Applied Occupational and Environmental Hygiene 1990;5:303-9.

5 Konieczny M, Harvey RG. Efficient reduction of polycyclic quinones, hydroquinones, and phenols to polycyclic aromatic hydrocarbons with hydriodic acid. Journal of Organic Chemistry 1979;44:4813-16.

6 Becher G, Bjorseth A. Determination of exposure to polycyclic aromatic hydrocarbons by analysis of human urine. Cancer Lett 1983;17:301-11.

7 Becher G, Bjorseth A. Multimethod determination of occupational exposure to polycyclic aromatic hydrocarbons in an aluminum plant. Carcinogenesis 1984;5:647-51.

8 Venier $\mathrm{P}$, Clonfero E, Cottica D, et al. Mutagenic activity and polycyclic aromatic hydrocarbon levels in urine of workers exposed to coal tar pitch volatiles in an anode plant. Carcinogenesis 1985;6:749-52.

9 Haugen A, Becher G, Benestad C, et al. Determination of polycyclic aromatic hydrocarbons in the urine, benzo(a)pyrene diol epoxide-DNA adducts in lymphocyte DNA, and antibodies to the adducts in sera from coke oven workers exposed to measured amounts of polycyclic aromatic hydrocarbons in the work atmosphere. Cancer Res 1986;46:4178-83.

10 Greenberg A, Liang C, Luo S, et al. Total human environmental exposure study (THEES) of benzo[a]pyrene: details of the chemical analyses. American Chemical Society meeting, Los Angeles, CA, 1988.

11 Yamasaki J, Ames BN. Concentration of mutagens from urine by absorption with the nonpolar resin XAD-2: cigarette smokers have mutagenic urine. Proc Natl Acad Sci USA 1975;74:3555-9.

12 Grimmer G, Dettbarn G, Naujack KW, Jacob J. Intake and excretion of polycyclic aromatic hydrocarbons of the masses $178,202,228$ and 252 in the urine of coke workers compared to non-exposed persons. 12th international symposium on polynuclear aromatic hydrocarbons, 1989.

13 Poirier MC, Santella R, Weinstein IB, Grunberger D, Yuspa 
SH. Quantitation of benzo(a)pyrene-deoxyguanosine adducts by radioimmunoassay. Cancer Res 1980;40:887-96.

14 Reddy MV, Gupta RC, Randerath E, Randerath K. ${ }^{32}$ P-postlabelling test for covalent DNA binding of chemicals in vivo: application to a variety of aromatic carcinogens and methylating agents. Carcinogenesis 1984;5:231-43.

15 Keimig SD, Kirby KW, Morgan DP, Keiser JE, Hubert TD. Identification of 1-hydroxypyrene as a major metabolite of pyrene in pig urine. Xenobiotica 1983;13:415-20.

16 Jongeneelen FJ, Hermans F, Anzion RB, Roelofs HM, Henderson PTh. Interindividual differences in hydroxylation of benzo[a]pyrene and pyrene in human liver preparations. In: Jongeneelen FJ, ed. Biological monitoring of occupational exposure to polycyclic aromatic hydrocarbons. Nijmegen: Scientific Publishers, 1987.

17 Jongeneelen FJ, Anzion RBM, Leijdekkers CM, Bos RP, Henderson PTh. 1-hydroxypyrene in human urine after exposure to coal tar and a coal tar derived product. Int Arch Occup Environ Health 1985;57:47-55.

18 Jongeneelen FJ, van Leeuwen FE, Oosterink S, et al. Ambient and biological monitoring of cokeoven workers: determinants of the internal dose of polycyclic aromatic hydrocarbons. $\mathrm{Br} \mathrm{J}$ Ind Med 1990;47:454-61.

19 Jongeneelen FJ, Azion RBM, Henderson PTh. Determination of hydroxylated metabolites of polycyclic aromatic hydrocarbons in urine. $J$ Chromatogr 1987;413:227-32.

20 Jacob J, Grimmer G, Raab G, Schmoldt A. The metabolism of pyrene by rat liver microsomes and the influence of various mono-oxygenase inducers. Xenobiotica 1982;12:45-53.

21 Butler J, Crossley P. Reactivity of polycylic aromatic hydrocarbons absorbed on soot particles. Atmospheric Environment 1981;15:91-4.

22 Vaessen HAMG, Jekel AA, Wilbers AAMM. Dietary intake of polycyclic aromatic hydrocarbon. PAH-Symposium, Nijmegen, 1986.

23 Obana H, Hori S, Kashimoto T, Kunita N. Polycyclic aromatic hydrocarbons in human fat and liver. Bull Environ Contamin Toxicol 1981;27:23-7.

24 Jongeneelen FJ, Akker WVD, Bos RP, et al. Mutagenicity of crude coal tar after activation with human liver preparations; formation of 1-hydroxypyrene as an indicator of the mutagenic activation capacity. In: Jongeneelen FJ, ed. Biological monitoring of occupational exposure to polycyclic aromatic hydrocarbons. Nijmegen: Scientific Publishers, 1987.

25 Howard JW, Fazio T. Review of polycyclic aromatic hydrocarbons in foods. J Assoc Off Anal Chem 1980;63:1077-1104.

26 Masuda Y, Kuratsune M. PAH in smoked fish, Katsuobushi. Gann 1971;62:27-30.

27 Osborne MR, Crosby NT. Occurrence of benzopyrenes in the environment. In Benzopyrenes. Cambridge: Cambridge University Press, 1987.

28 Lintas C, DeMatthaeis MC. Determination of benzo[a]pyrene in smoked, cooked and toasted food products. Food and Cosmetic Toxicology 1979;17:325-8.

29 Larsson BK, Sahlber GP, Eriksson AT, Busk LA. Polycyclic aromatic hydrocarbons in grilled food. Journal of Agricultural and Food Chemistry 1983;31:867-73.

30 Lijinsky W, Shubik P. Benzo[a]pyrene and other polynuclear hydrocarbons in charcoal-broiled meat. Science 1964;145: 53-5.

31 Doremire ME, Harmon GE, Pratt DE. 3,4-benzopyrene in charcoal grilled meats. Journal of Food Science 1979;44:622-3.

32 Buckley T, Waldman J, Freeman NCG, Lioy P. Calibration, intersampler comparison, and field application of a new PM10 personal air sampling impactor. Aerosol Science and Technology 1991;14:380-38.

33 Swanson DH, Walling JF. Use of ultrasonics in the rapid extraction of $\mathrm{Hi}-\mathrm{Vol}$ filters for benzo[a]pyrene $(\mathrm{BaP})$ analysis. Chromatography Newsletter 1981;9:25-6.

34 Lioy PJ, Waldman JM, Greenberg A, Harkov R, Pietarinen C. The total human environmental exposure study (THEES): comparison of the inhalation and food pathways. Arch Environ Health 1988;43:304-12.

35 Greenberg A, Luo S, Hsu CH, Creighton P, Waldman J, Lioy P. Benzo[a]pyrene in composite prepared meals; results from the THEES (total human exposure to environmental substances) Study. Polycyclic Aromatic Compounds 1990;1:221-31.

36 Howard JW, Fazio T, White RH, Klimech BA. Extraction and estimation of polycyclic aromatic hydrocarbons in total diet. $J$ Assoc Off Anal Chem 1986;51:122-9.

$37 \mathrm{Xia} \mathrm{X}$, Wu M, Rao Z. Determination of benzo[a]pyrene in Beijing roast duck and roast lamb. Shipih Kexue (Beijing) 1985;61:1-3.

38 US Environmental Protection Agency. The human food chain as an environmental exposure pathway. Las Vegas, Nevada: Environmental Monitoring Systems Laboratory, 1983. (EPA 600/x-83-001).

39 Vaessen HAMG, Jekel AA, Wilbers AAMM. Dietary intake of polycyclic aromatic hydrocarbon. PAH-Symposium, Nijmegen: 1986.

40 Santodonato J, Howard P, Basu D. Health and ecological assessment of polynuclear aromatic hydrocarbons. Journal of Environmental Pathology and Toxicology 1981;5:1-364.

41 Buckley TJ, Benzo/a/pyrene (BaP) metabolites and 1-hydroxypyrene as urinary biomarkers for human environmental exposure to BaP. Department of Environmental Science, Rutgers: The State University of New Jersey, 1991. (Dissertation.)

42 Lindstedt G, Sollenberg J. Polycyclic aromatic hydrocarbons in the occupational environment. Scand $J$ Work Environ Health 1982;11:311-16.

43 International Agency for Research on Cancer. Monographs on the evaluation of the carcinogenic risk of chemicals to humans. Vol 34. polynuclear aromatic compounds. Part 3. industrial exposures in aluminium production, coal gasification, coke production, and iron steel founding. Lyon: IARC, 1984.

44 Grimmer G, Dettbarn G, Naujack K-W, Jacob J. Excretion of hydroxy-derivatives of polycyclic aromatic hydrocarbons of the masses $178,202,228$ and 252 in the urine of coke and road workers. 18th international symposium on environmental analytical chemistry. Barcelona: 1988.

45 Dennis JM, Massey RC, McWeeny DJ, Watson DH. Polycyclic aromatic hydrocarbons in the UK diet. Chemical Toxicology 1983;5:569-74.

46 Foth H, Kahl R, Kahl GF. Pharmacokinetics of low doses of benzo[a]pyrene in the rat. Food Chemistry and Toxicology 1988;26:45-51.

47 Chipman JK, Bhave PC, Millburn P. Metabolism and excretion of benzo[a]pyrene in the rabbit. Xenobiotica 1982;12:397-404.

48 Jacob J, Brune H, Gettbarn G, et al. Urinary and faecal excretion of pyrene and hydroxypyrene by rats after oral, intraperitoneal, intratracheal or intrapulmonary application. Cancer Letters 1989;46:15-20.

Accepted 8 April 1991 